\title{
Monozygotic Twins Concordant for Common Variable Immunodeficiency: Strikingly Similar Clinical and Immune Profile Associated With a Polygenic Burden
}

OPEN ACCESS

Edited by:

Tomas Kalina,

Charles University, Czechia

Reviewed by:

Esther De Vries,

Tillburg University, Netherlands

Marielle Van Gijn,

University Medical Center

Utrecht, Netherlands

${ }^{*}$ Correspondence:

Susana L. Silva

susanasilva@medicina.ulisboa.pt

Specialty section:

This article was submitted to Primary Immunodeficiencies,

a section of the journal

Frontiers in Immunology

Received: 18 June 2019

Accepted: 07 October 2019

Published: 22 November 2019

Citation:

Silva SL, Fonseca M, Pereira MLM,

Silva SP, Barbosa RR,

Serra-Caetano A, Blanco E, Rosmaninho $P$, Pérez-Andrés $M$,

Sousa $A B$, Raposo AASF,

Gama-Carvalho M, Victorino RMM, Hammarstrom L and Sousa AE (2019)

Monozygotic Twins Concordant for Common Variable Immunodeficiency:

Strikingly Similar Clinical and Immune

Profile Associated With a Polygenic

Burden. Front. Immunol. 10:2503.

doi: 10.3389/fimmu.2019.02503

\author{
Susana L. Silva ${ }^{1,2,3 *}$, Mariana Fonseca ${ }^{1,2}$, Marcelo L. M. Pereira ${ }^{4}$, Sara P. Silva ${ }^{1,2,3}$, \\ Rita R. Barbosa ${ }^{1}$, Ana Serra-Caetano ${ }^{1,2}$, Elena Blanco ${ }^{5,6}$, Pedro Rosmaninho ${ }^{1,2}$, \\ Martin Pérez-Andrés ${ }^{5,6}$, Ana Berta Sousa ${ }^{1,2,3}$, Alexandre A. S. F. Raposo ${ }^{1,2}$, \\ Margarida Gama-Carvalho ${ }^{4}$, Rui M. M. Victorino ${ }^{1,2,3}$, Lennart Hammarstrom ${ }^{7}$ and \\ Ana E. Sousa ${ }^{1,2}$
}

${ }^{1}$ Faculdade de Medicina, Instituto de Medicina Molecular João Lobo Antunes, Universidade de Lisboa, Lisbon, Portugal, ${ }^{2}$ Centro de Imunodeficiências Primárias, Centro Académico de Medicina de Lisboa, Centro Hospitalar Universitário Lisboa Norte and Faculdade de Medicina da Universidade de Lisboa and Instituto de Medicina Molecular, Lisbon, Portugal, ${ }^{3}$ Centro Hospitalar Universitário Lisboa Norte, Hospital de Santa Maria, Lisbon, Portugal, ${ }^{4}$ Faculty of Sciences, BiolSI-Biosystems \& Integrative Sciences Institute, University of Lisboa, Lisbon, Portugal, ${ }^{5}$ Department of Medicine, Cancer Research Centre (IBMCC, USAL-CSIC), Cytometry Service (NUCLEUS), Institute of Biomedical Research of Salamanca (IBSAL), University of Salamanca (USAL), Salamanca, Spain, ${ }^{6}$ Biomedical Research Networking Centre on Cancer-CIBER-CIBERONC, Number CB16/12/00400, Institute of Health Carlos III, Madrid, Spain, ${ }^{7}$ Department of Laboratory Medicine, Karolinska Institutet, Stockholm, Sweden

Monozygotic twins provide a unique opportunity to better understand complex genetic diseases and the relative contribution of heritable factors in shaping the immune system throughout life. Common Variable Immunodeficiency Disorders (CVID) are primary antibody defects displaying wide phenotypic and genetic heterogeneity, with monogenic transmission accounting for only a minority of the cases. Here, we report a pair of monozygotic twins concordant for CVID without a family history of primary immunodeficiency. They featured a remarkably similar profile of clinical manifestations and immunological alterations at diagnosis (established at age 37) and along the subsequent 15 years of follow-up. Interestingly, whole-exome sequencing failed to identify a monogenic cause for CVID, but unraveled a combination of heterozygous variants, with a predicted deleterious impact. These variants were found in genes involved in relevant immunological pathways, such as JUN, PTPRC, TLR1, ICAM1, and JAK3. The potential for combinatorial effects translating into the observed disease phenotype is inferred from their roles in immune pathways, namely in $\mathrm{T}$ and $\mathrm{B}$ cell activation. The combination of these genetic variants is also likely to impose a significant constraint on environmental influences, resulting in a similar immunological phenotype in both twins, despite exposure to different living conditions. Overall, these cases stress the importance of integrating NGS data with clinical and immunological phenotypes at the single-cell level, as provided by multi-dimensional flow-cytometry, in order to understand the complex genetic landscape underlying the vast majority of patients with CVID, as well as those with other immunodeficiencies.

Keywords: CVID, flow-cytometry, polygenic disease, genetics, WES, monozygotic twins 


\section{BACKGROUND}

Monozygotic twins provide a unique opportunity to evaluate the relative contribution of genome and environment to the development and evolution of the immune system throughout life (1-3). A recent study on a large twin cohort suggests that life experience is the main determinant, challenging the importance of genetic background (2). Monozygotic twins (MZ) also provide a valuable tool to investigate complex diseases of the immune system like Common Variable Immunodeficiency (CVID).

CVID is defined overall by a marked decrease in serum IgG and IgA, normal or decreased serum IgM, poor antibody responses to vaccines and absence of other identifiable causes for hypogammaglobulinemia (4). However, almost all components of the immune system may feature alterations, with high heterogeneity between patients $(5,6)$. Given the marked clinical heterogeneity, multiparametric flow-cytometry is instrumental to detail the individual immune profile (7-10), allowing personalized approaches to treatment and monitoring of comorbidities $(7,10)$.

A genetic basis for CVID was already recognized in 1968 (11), though the identification of the underlying molecular defects has been hampered in the majority of patients, which usually do not have a family history. In recent years, next generation sequencing (NGS) strategies, including genome-wide association and wholeexome/genome sequencing studies (WES/WGS) (9, 12-19), have facilitated the identification of an increasing list of genes, with heterozygous or biallelic variants associated with monogenic CVID (9, 12-20). Nevertheless, monogenic transmission is currently assumed in only $15-25 \%$ of the patients with CVID, in association with pathogenic variants in genes related mostly to B-cell activation, T-cell signaling and cytokine expression $(14,15,17,20)$. Conversely, CVID is likely to be polygenic in the majority of patients, resulting from multiple epistatic interactions with cumulative effects $(12,21)$. Consistently, CVID may develop clinically at any age, suggesting progressive and cumulative deterioration of $\mathrm{B}$-cell functions, in a putative multifactorial pathogenic process $(8,22)$.

The contribution of non-heritable influences, such as infectious exposure, to the establishment of the clinical and immunological phenotypes in CVID is also recognized (23). The possible role of viral infections as triggers to disease onset, and the impact of microbiome are illustrative ongoing debates $(23,24)$. Twin studies thus provide a powerful model to dissect the relative contributions of heritable and non-heritable variables to the establishment of clinical and immunological profiles, but have so far been poorly explored, given the rarity of these cases $(2,3)$.

We provide here the first report of $\mathrm{MZ}$ twins concordant for CVID. Extensive phenotypic profile of circulating B and Tcell subsets was obtained by flow-cytometry at diagnosis and during 15-years follow-up. The twins featured a remarkably similar immunologic and clinical profile, despite the absence of a recognizable monogenic cause, being 50 years-old, and having lived apart for many years. Importantly, WES allowed us to identify a combination of variants with putative impact in the immune system that is not shared by their progenitors or progeny, supporting a polygenic basis for the CVID phenotype and their concordant immune evolution.

\section{CASE PRESENTATION}

CVID diagnosis was performed at 37 years of age in a pair of Caucasian MZ twins, living in Lisbon, Portugal, born from nonconsanguineous parents and with no family history of primary immunodeficiency. They presented a remarkably similar clinical and immunological profile throughout 15 years of follow-up, despite distinct living conditions (jobs, housing, and nuclear families) since age 25 .

At diagnosis, both twins featured severe hypogammaglobulinemia, with very low serum IgG $(<0.3$ and $1.65 \mathrm{~g} / \mathrm{L}$, cases 1 and 2 , respectively), undetectable $\operatorname{IgA}$ $(<0.25 \mathrm{~g} / \mathrm{L})$ and $\operatorname{IgM}(<0.19 \mathrm{~g} / \mathrm{L})$, and no increase in titres of specific IgG upon polysaccharide pneumococcal and conjugated Haemophilus influenzae vaccinations. They had a low frequency of circulating total and memory B cells, particularly of switched-memory B cells, with no expansions of transitional B cells or of cells expressing low levels of CD21 (Figure 1A), thus featuring an identical EuroClass classification $\mathrm{B}^{+} \mathrm{smB}^{-} \operatorname{Tr}^{\text {norm }} 21^{\text {norm }}$ (25). They also exhibited comparable naïve/memory subset distribution and expression of activation markers in CD4 and CD8 T cells (Figure 1B), with a defect in CD45 alternative splicing leading to the persistence of CD45RA in memory/effector T cells. Functional studies in T cells revealed an equal production of IL-2, IL-4, IFN $\gamma$, and IL-17 (Figure 1B) and impairment of proliferative responses to recall antigens, despite the relative high levels of proliferative responses to mitogens (Figure 1C).

Along the follow-up there was concordant evolution of their immunological profile, shown by the PCAs obtained at age 50 with the EuroFlow protocols (Figure 2A). The detailed phenotypic evaluation of circulating B cells revealed severe B-cell depletion (total $\mathrm{B}$ cells $<1 \%$ ) in both, with residual preservation of $\mathrm{IgG3}^{+} \mathrm{CD} 27^{-}$memory B cells detected by high-sensitivity methods $(7,26,27)$ (Figure 2B). This profile, which reflects extreme deterioration of IgG-switching capacity in memory B cells, is compatible with the most severe (CVID-6) subgroup, as recently reported in the literature (7).

The type and severity of clinical manifestations before diagnosis and during follow-up have also been very similar. Both twins featured upper and lower respiratory infections since their twenties, with progressively increased frequency leading to several hospital admissions for pneumonia; bilateral bronchiectasis; and nasal polypectomy at age 32 in both. Upon diagnosis, intravenous IgG replacement was initiated, leading to serum IgG levels above $800-900 \mathrm{mg} / \mathrm{dL}$ and a marked decline in the frequency of infectious episodes. Both maintained persistent sinusitis, with recurrent exacerbations mostly in conjunction with $H$. influenza infection, and intermittent non-infectious diarrhea compatible with minor chronic lymphocytic infiltration, observed in duodenal and colon mucosa.

This remarkably similar profile in MZ twins strongly suggested that the genetic background is the main contributor 
A

CVID-1

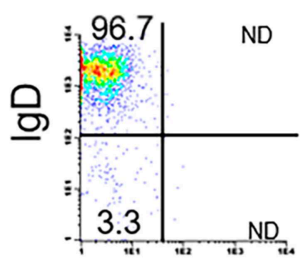

CD27
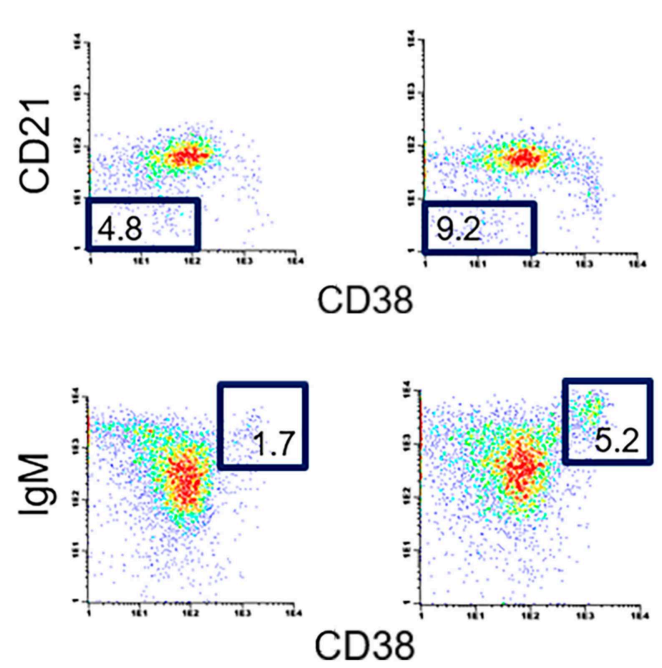

\section{CVID-2}

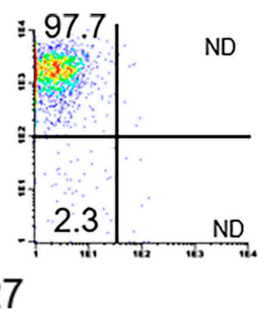

C
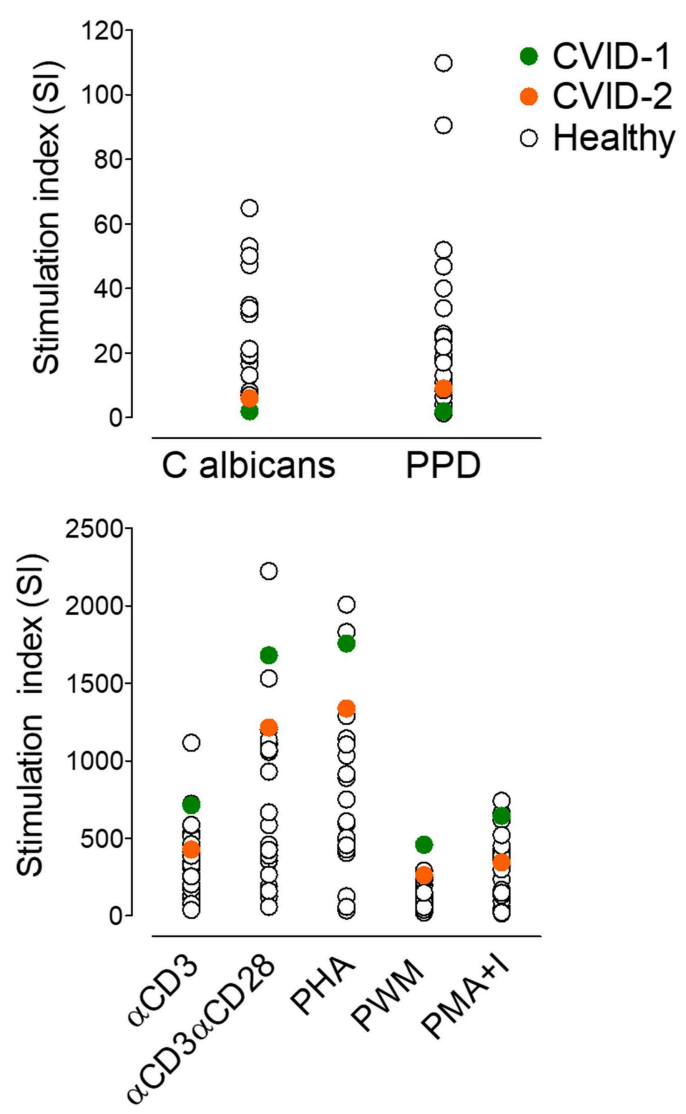

B

\begin{tabular}{ccccccccccc}
\hline & & Naïve & RO+27+ & RO+27- & HLA-DR+ & IL-2+ & IL-4+ & IFN-Y+ & IL-17+ \\
\hline $\begin{array}{c}\text { \% within } \\
\text { CD4 T-cells }\end{array}$ & CVID-1 & 64.4 & 33.7 & 1.9 & 8.6 & 35.3 & 1.2 & 5.7 & 0.4 \\
\hline $\begin{array}{c}\text { CVID-2 } \\
\text { CD8 Tithin }\end{array}$ & 61.3 & 36.8 & 1.8 & 9.3 & 43.9 & 1.9 & 6.9 & 0.5 \\
\hline
\end{tabular}

FIGURE 1 | Immune phenotype at CVID diagnosis at age 37 in the MZ twins. (A) Representative plots of the flow-cytometry analysis of switched-memory B cells (top), CD2 $1^{\text {low }} \mathrm{CD} 38^{\text {low }} \mathrm{B}$ cells (middle) and transitional B cells (bottom). Numbers represent the percentage of the given population within CD19+ cells (3.0\%/4.2\% in case-1/case-2, respectively). (B) Frequency of naïve and memory subpopulations, expression of activation marker $\mathrm{HLA}^{-D R^{+}}$, and frequency of cells producing IL-2, IL-4, IFN- $\gamma$, and IL-17 within CD4 and CD8 T cells (1,777/1,380 lymphocytes/ $\mu$ L; CD4 T cells 42.2\%/43.6\%; CD8 T cells 44.1\%/39.8\%; in cases 1/2, respectively) (C) Lymphoproliferative responses upon culture with antigens (top) and mitogens (bottom) in comparison with healthy adult individuals.

to their clinical and immunological evolution. We therefore sequenced their whole exome (WES) using DNA extracted from blood samples. We focused the analysis on genes involved in immunological pathways, identifying SNVs with a nonsynonymous coding effect predicted to be either probably damaging or deleterious $(28,29)$, or frame shift variants (see Methods). We also looked for variants affecting mRNA splice sites, but we found no variants in genes reported as monogenic causes of CVID. In fact, WES analysis was unable to reveal a monogenic cause for CVID. However, we identified in both a combination of 7 heterozygous SNVs, occurring in JAK3, JUN, LYST, MBL2, ICAM1, and TLR1 (Table 1 and Figure 3A). None of these 6 genes has previously been shown to be associated with monogenic CVID $(15,32)$. A compound heterozygous change, combining one variant from each parent, was found in ICAM1. 
A

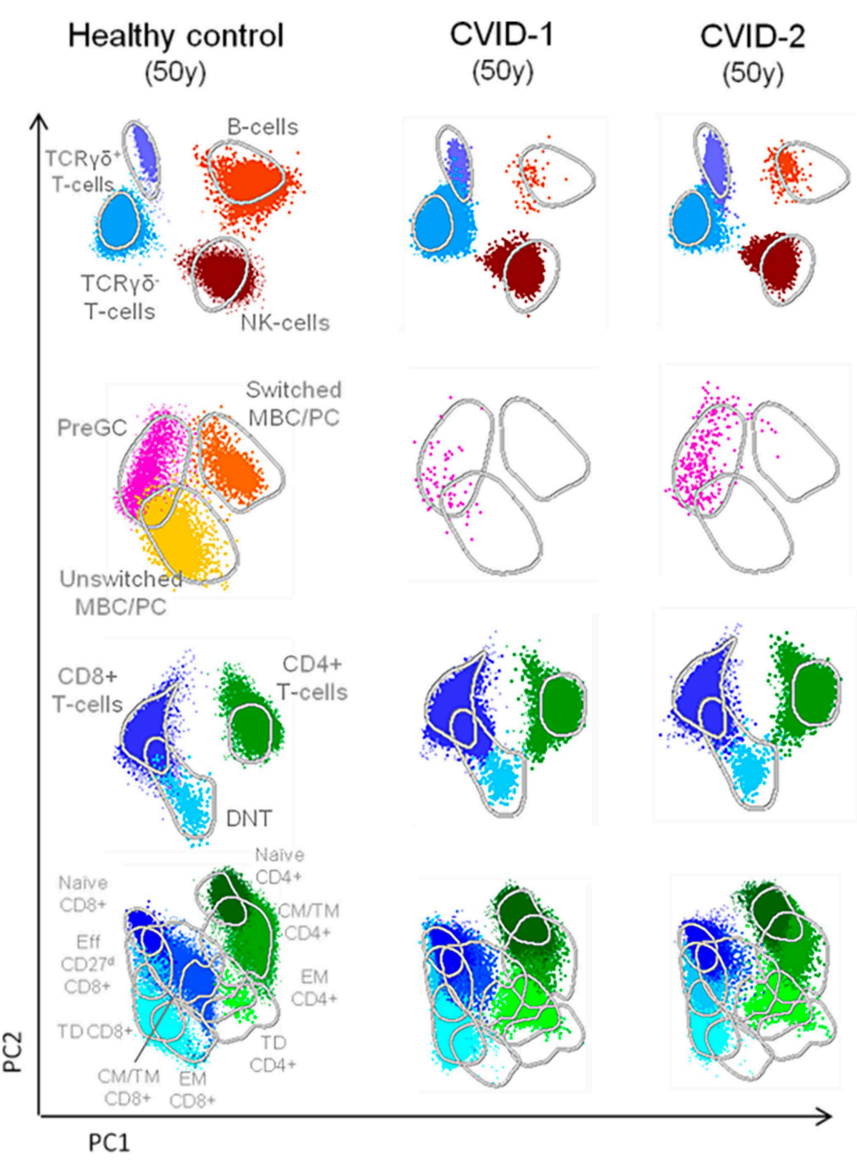

B

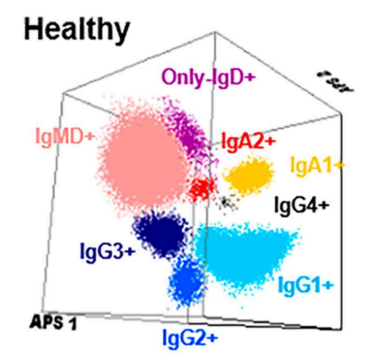

CVID-1
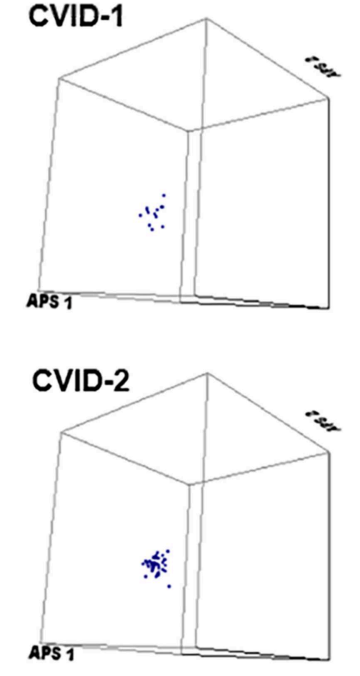

FIGURE 2 | Supervised flow-cytometric analysis of blood lymphocytes in MZ twins concordant for CVID at age 50. (A) Principal component analysis (PCA) multidimensional view of the distribution of major lymphocyte subsets analyzed with the EuroFlow PID orientation tube in $1 \times 10^{6}$ peripheral blood leukocytes. (B) Distribution of memory $B$ cells according to the surface membrane expression of the $\lg H$-isotypes $(\lg M, \lg D, \lg G 1, \lg G 2, \lg G 3, \lg G 4, \lg A 1$, and $\lg A 2)$ in $5 \times 10^{6}$ peripheral blood leukocytes analyzed from an age-matched healthy donor and the two twins with CVID (7, 8, 26).

In face of the defect in CD45 alternative splicing observed in T cells, we additionally looked at variants in PTPRC (CD45). We found the twins were heterozygous carriers of C77G (Table 1 and Figure 3A), a heterozygous variant that was previously reported in heterozigosity in CVID patients $(33,34)$.

In order to elucidate the segregation of the identified variants and their possible associations with clinical manifestations and/or immunological profile, their parents and children were also evaluated. Neither the progenitors nor the progeny had any severe/recurrent infections or immune-mediated diseases, and all had normal levels of serum $\operatorname{IgG}$, IgA, and $\operatorname{IgM}$, except for one son with a past-history of autoimmune thrombocytopenia (III:3, Figure 3A). Parents and children were genotyped for the 8 genetic variants (Figure 3A) and the variants considered were found to be split between parents, and none of the descendants inherited the combination of variants observed in the twins. Due to the frequent onset of CVID-associated clinical manifestations in adulthood, prospective follow-up of the offspring, particularly of the son with a past-history of autoimmune thrombocytopenia, will be important to complete our current interpretation of NGS data.

\section{METHODS}

\section{Patients and Relatives}

Longitudinal data obtained from a pair of $\mathrm{MZ}$ twins followed at Centro de Imunodeficiências Primárias, of Lisbon Academic Medical Center. The patients met the European Society for Immunodeficiencies (ESID) diagnostic criteria for CVID at the time of enrolment (35). Patients and relatives gave written informed consent. The study was approved by the ethical boards of the Faculty of Medicine of University of Lisbon and Centro Hospitalar Universitário Lisboa Norte.

\section{Immunological Studies}

Phenotypic analysis was performed by flow-cytometry during follow-up using previously described protocols $(8,36,37)$ and different cytometers (FACSCalibur, FACSCanto and 
TABLE 1 | Selected SNVs with impact in the immune system identified by WES.

\begin{tabular}{|c|c|c|c|c|c|c|c|c|}
\hline Gene & Change coordinates & $\begin{array}{l}\text { Ensembl } \\
\text { transcript ID }\end{array}$ & $\begin{array}{l}\text { Protein variant } \\
\text { (HGVS) }\end{array}$ & dbSNP ID & EXAC (MAF EUR) & PolyPhen & SIFT & $\begin{array}{l}\text { Immunological role of the gene-encoded } \\
\text { protein }\end{array}$ \\
\hline JAK3 & chr19:17952472 T/C & $\begin{array}{l}\text { ENSTO0000428406 } \\
\text { ENST00000458235 } \\
\text { ENST00000527670 } \\
\text { ENST00000534444 }\end{array}$ & T321A & NA & NA & PD & $\mathrm{T}$ & $\begin{array}{l}\text { Member of Janus kinase family of tyrosine kinases; } \\
\text { Cytokine receptor-mediated intracellular signal } \\
\text { transduction }\end{array}$ \\
\hline \multirow[t]{2}{*}{ ICAM1 } & chr19:10394792 G/A & ENST00000264832 & G241R & rs1799969 & 0,1102 & PD & $\mathrm{D}$ & $\begin{array}{l}\text { Cell surface glycoprotein with major role in cell-cell } \\
\text { adhesion, in endothelia and immune cells }\end{array}$ \\
\hline & chr19:10395468 G/A & $\begin{array}{l}\text { ENST00000423829 } \\
\text { ENST00000264832 }\end{array}$ & R397Q & rs5497 & 0,0006 & $\mathrm{PD}$ & $\mathrm{D}$ & \\
\hline JUN & chr1:59248405 C/G & ENST00000371222 & G113A & rs1462279538 & NA & PD & $\mathrm{D}$ & $\begin{array}{l}\text { Transcription Factor AP- } 1 \text { interacts with specific } \\
\text { target DNA sequences to regulate gene expression } \\
\text { in the immune system }\end{array}$ \\
\hline LYST & chr1:235972992 G/T & $\begin{array}{l}\text { ENST00000536965 } \\
\text { ENSTO0000389794 } \\
\text { ENST00000389793 }\end{array}$ & P376T & rs770362521 & $3 \times 10^{-5}$ & $\mathrm{PD}$ & $\mathrm{T}$ & $\begin{array}{l}\text { Regulates intracellular protein trafficking in } \\
\text { endosomes; Mutations associated with } \\
\text { Chediak-Higashi syndrome with impaired cytotoxic } \\
\text { lymphocyte function (30) }\end{array}$ \\
\hline TLR1 & $\begin{array}{l}\text { chr4: 38799956; } \\
\text { NM_003263.4:c.497del }\end{array}$ & $\begin{array}{l}\text { ENST00000308979 } \\
\text { ENST00000502213 }\end{array}$ & K166fs & rs761749628 & 0,0003454 & NA & $\mathrm{D}$ & $\begin{array}{l}\text { Member of the Toll-like receptor family, with a role in } \\
\text { pathogen recognition and activation of innate } \\
\text { immunity. Identified as a critical mediator of intestinal } \\
\text { immunity }\end{array}$ \\
\hline MBL2 & chr10:54531242 G/A & ENST00000373968 & $\mathrm{R} 52 \mathrm{C}$ & rs5030737 & 0,076 & PD & $\mathrm{D}$ & $\begin{array}{l}\text { Belongs to collectin family. Important element in the } \\
\text { innate immune system } \\
\text { Variants associated with susceptibility to } \\
\text { autoimmunity and infections (31) }\end{array}$ \\
\hline PTPRC & chr1:198665917 C/G & $\begin{array}{l}\text { ENST00000352140 } \\
\text { ENSTO0000367376 } \\
\text { ENST00000418674 } \\
\text { ENSTO0000442510 } \\
\text { ENSTO0000529828 }\end{array}$ & $\mathrm{C} 77 \mathrm{G}$ & rs17612648 & 0,016 & $S$ & $\mathrm{~N} / \mathrm{A}$ & $\begin{array}{l}\text { Important for efficient T and B-cell antigen receptor } \\
\text { signal transduction } \\
\text { CD45RA persistence in memory T cells in } \\
\text { alternative splicing defect }\end{array}$ \\
\hline
\end{tabular}

HGVS, human genome variation society; NA, not available; MAF, minor allele frequency; EUR, European; PD, probably damaging; $S$, synonimous; T, tolerated; $D$, deleterious. 
A
ICAM1 (G241R)
JAK3 (T321A)
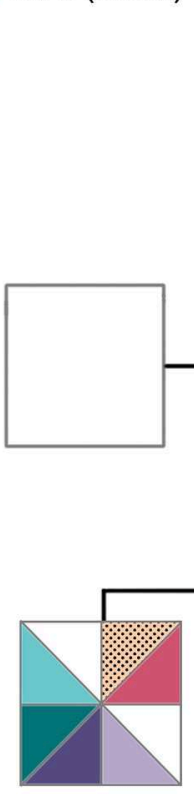

III:1

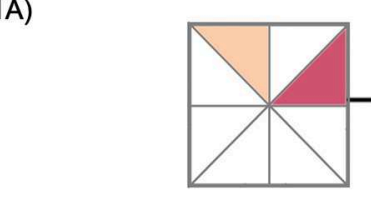

I:1
\% ICAM1 (R397Q)

\section{TLR1 (K166fs)}

JUN (G113A)

LYST (P376T)

MBL2 (R52C)

CD45 (C77G)

$\mathrm{l}: 2$

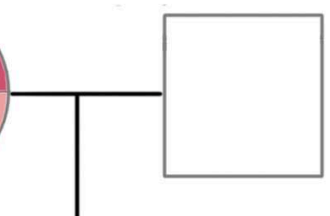

II:1

II:2

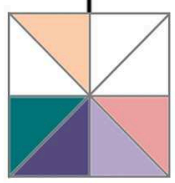

III:3

B

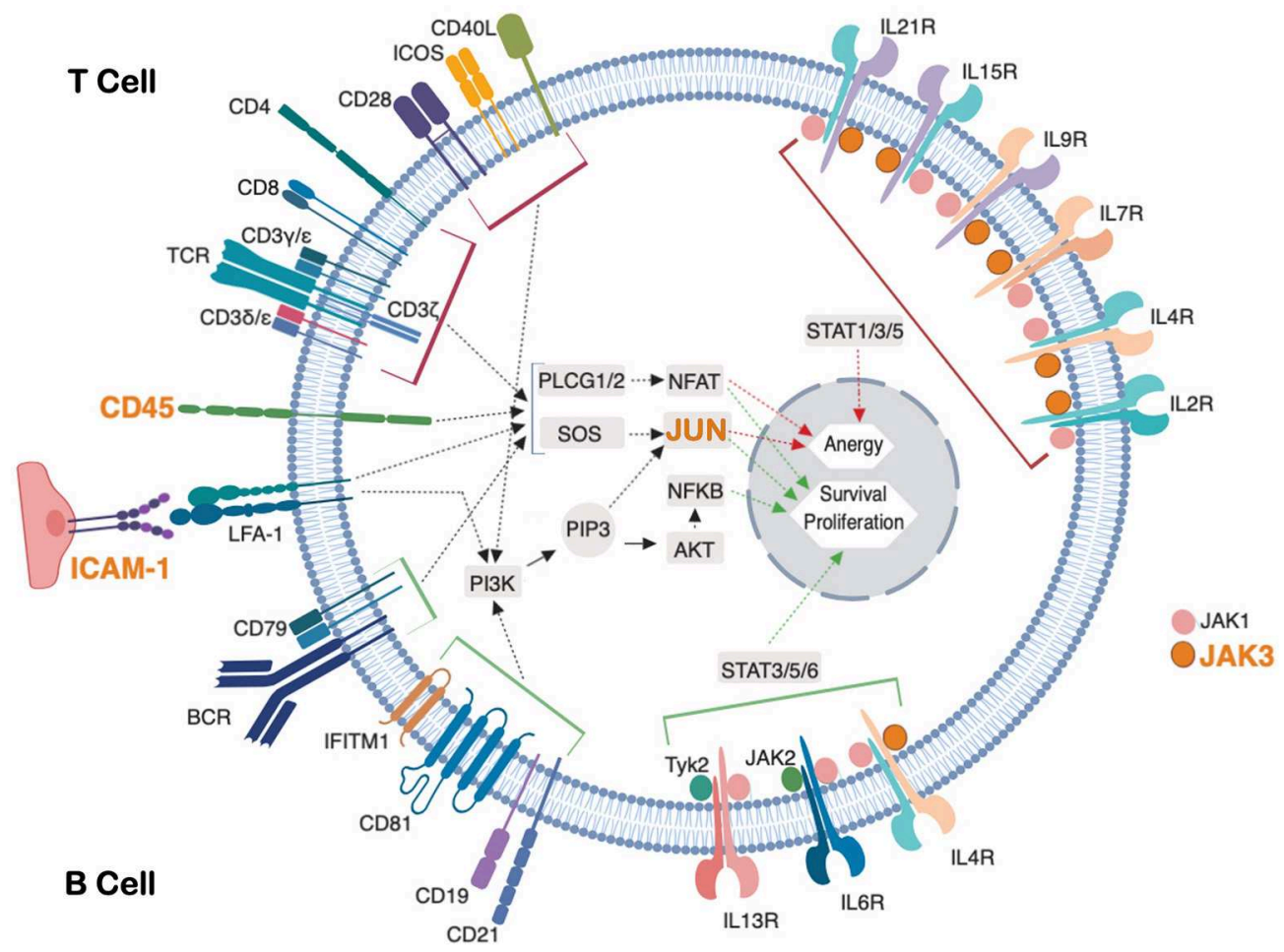

FIGURE 3 | Identified genetic variants and predicted functional impact on B and T-cell activation pathways. (A) Family tree of the patients. The sectors and color patterns represent the 8 genetic variants identified in the 7 listed genes, and their presence/absence in both the progenitors and the children of the two siblings. Each (Continued) 
FIGURE 3 | sector corresponds to one specific variant. Paternally inherited variants are represented on the left, and maternal variants on the right, with a color code per gene, next to the gene ID and identified variant (in parenthesis). The black dotted pattern highlights the maternal variant in the case of ICAM, for which the patients have two altered alleles. (B) Role of affected genes in T and B-cell activation processes. The figure represents a generic lymphoid cell with the major membrane receptors, signaling molecules and transcription factors (identified by their names) and intracellular signaling pathways (identified by arrows) involved in the activation process. Red and green arrows represent the final stages of the lymphocyte activation pathways leading to the expression of genes that promote anergy (red) or survival/proliferative responses (green) within the cell nucleus. The top half of cell highlights proteins and processes specific for $\mathrm{T}$ cell activation and the bottom half those specific for B-cell activation. The names of proteins encoded by genes that present potentially pathogenic variants are presented in orange. The figure compiles all the information that was retrievable from pathways databases and literature search regarding the connections between genes presented in (A) and the B and $T$ cell activation pathways. Of these 7 genes, LYST did not present any connection to these processes, whereas two others (MBL2 and TLR1) have reported functions in lymphocyte activation but their connection to signaling pathways remains unclear and are thus not represented in the figure.

LSR-Fortessa X-20 flow-cytometers, Becton/Dickinson Biosciences (BD), San José, CA). Briefly, stainings with monoclonal antibodies were performed in whole blood after red blood cells lysis using BD FACS Lysing Solution (BD Biosciences), and a minimum of 100,000 lymphocytes were acquired per sample with data analyzed using CellQuest Software (BD Biosciences) and FlowJo Software (Tree Star Inc., Ashland, OR). More recently, $10^{7}$ nucleated cells were stained with the EuroFlow 12-color Ig-isotype B-cell tube and bulk-lyse standard operating procedure (SOP; www.EuroFlow.org), $\geq 5$ $\times 10^{6}$ leukocytes were acquired in LSR-Fortessa X-20, with instrument set-up and calibration performed according to the EuroFlow SOP (38), and data analyzed with Infinicyt software (Cytognos S.L., Salamanca, Spain).

Cytokine production was assessed at the single-cell level in peripheral blood mononuclear cells (PBMC) freshly isolated by Ficoll-Hypaque density gradient (Amersham Pharmacia Biotech, Uppsala, Sweden), as described (39). Briefly, after a 4-h culture with phorbol myristate acetate (PMA; $50 \mathrm{ng} / \mathrm{mL}$, Sigma-Aldrich) plus ionomycin (500 ng/mL; Calbiochem, Merck Biosciences, Nottingham, U.K.), in the presence of brefeldin A $(10 \mu \mathrm{g} / \mathrm{mL}$; Sigma-Aldrich), PBMC were surface stained, fixed, permeabilized, and stained intracellularly with monoclonal antibodies against IL-2, IL-4, IFN- $\gamma$, and IL-17, as described (36). Flow-cytometric analysis was subsequently performed as described above.

Lymphocyte proliferation was evaluated as follows: $10^{5}$ freshly isolated PBMCs were cultured in a 96-well plate in the absence or presence of mitogens PHA $(20 \mu \mathrm{g} / \mathrm{mL})$, anti-CD3 $(1 \mu \mathrm{g} / \mathrm{mL})$, anti-CD3 anti-CD28 $(1 \mu \mathrm{g} / \mathrm{mL})$, PWM $(1 \mu \mathrm{g} / \mathrm{mL})$ and PMA $(50 \mathrm{ng} / \mathrm{mL})+$ ionomycin $(500 \mathrm{ng} / \mathrm{mL})$ and antigens Candida albicans $(40 \mu \mathrm{g} / \mathrm{mL})$ and PPD $(5 \mu \mathrm{g} / \mathrm{mL})$, for 3 and 6 days, respectively, at $37^{\circ} \mathrm{C}, 5 \% \mathrm{CO}_{2}$. Proliferation was assessed by $3 \mathrm{H}$ Thy (Amersham Pharmacia Biotech) incorporation in the last $8 \mathrm{~h}$ of culture. Results were expressed as stimulation indexes (SI) which represents the ratio of the mean counts per minute $(\mathrm{cpm})$ in the presence of a given mitogen or antigen over the mean cpm in the absence of the stimulus.

\section{Whole Exome Sequencing}

Genomic DNA was extracted from peripheral blood, subjected to library construction using the Agilent Sure Select Human All Exon $50 \mathrm{Mb}$ kit (Agilent Technologies) and sequenced on a Hiseq2000 Illumina sequencer (BGI-Shenzhen, China) (40). Low-coverage and low-quality Single-Nucleotide Variants
(SNVs) were removed as described (41). High-quality reads were aligned to the reference human genome (GRCh37/hg 19) and annotated with SnpEff Tool. Non-synonymous SNVs predicted to be probably damaging or deleterious [either by PolyPhen 2.2.2 (28) or SIFT 5.1.1 (29)], or frameshift variants, regardless of the minor allele frequency were filtered and prioritized. Criteria to further narrow down the candidate gene list were applied as previously described (42). Extensive search was performed in the literature, interactome and pathways databases regarding the roles of identified genes in the immune system, particularly concerning their involvement in B and T-cell activation pathways, illustrated in Figure 3B.

\section{DISCUSSION}

Here we report the first study of a pair of $\mathrm{MZ}$ twins concordant for CVID. They featured remarkable similarity in clinical and immunological phenotypes at diagnosis and during 15-year follow-up, and the analysis of WES data did not identify pathogenic variants in genes previously reported in association with monogenic CVID. In contrast, we identified 7 non-synonymous coding variants with predicted damaging/deleterious impact on the 6 proteins coded by the involved genes. These genes integrate relevant immune pathways and are therefore likely to have a clinical impact, supporting a polygenic burden for CVID, as well as to constrain the evolution of immunological profiles, leading to the high degree of similarity observed between the twins, despite having led separate lives for over 25 years. The clinical and immunological outcome in the twins likely results from the accumulation of distinct functional impairments, due to variants in genes related to critical immunological pathways $(12,21)$, as none of the identified heterozygotic variants can independently explain their clinical/immunological picture. Consistent with this polygenic model, there is a potential combinatorial impact of the observed SNVs in B and T-cell activation, as illustrated in Figure 3B. The absence of clinical and immunological manifestations in close family members also argues in favor of a pathogenic burden derived from the unique combination of variants shared by the twins.

There are previous reports of CVID patients who are heterozygous carriers of C77G in CD45 $(33,34)$. CD45 is known to be important for efficient $\mathrm{T}$ and $\mathrm{B}$-cell antigen receptor signal transduction and for control of signaling thresholds through TCR $(31,43)$. C77G is the most common cause of CD45 abnormal 
splicing in European populations (44), which leads to the persistence of CD45RA in memory T cells $(45,46)$. The twins are heterozygous for $\mathrm{C} 77 \mathrm{G}$ and exhibit a strong mitogenic response to anti-CD3, but markedly diminished proliferative responses to the tested recall antigens. Our data add to previous reports $(33,34)$ favoring a role for this SNV in a polygenic scenario for CVID, although the frequency of (heterozygous) carriers of C77G in CD45 was not increased in a large CVID cohort (33) and different clinical phenotypes have been associated with $\mathrm{C} 77 \mathrm{G}$ in CD45.

Obviously, we cannot exclude a role for other variants, such as non-coding variants, in the genes that we mentioned, nor in other genes, that may impact in the clinical and immunological phenotype of the twins. Nevertheless, it is worth noting that 4 out of the 7 selected genes with variants act on both $\mathrm{T}$ and $\mathrm{B}-$ cell receptor signaling-pathways, namely JUN, CD45 (PTPRC), and ICAM1 (Figure 3B); and MBL2 and TLR1, influence these processes through as yet unidentified mechanisms (see below) (30, 31, 46-53). Furthermore, the presence of a potentially damaging variant in the JAK3 kinase may influence the cytokine receptor-mediated intracellular signal transduction, with crucial implications in the differentiation, function and survival of $\mathrm{B}$ and T cells (Figure 3B) (54). Other immune pathways that may be influenced by this group of variants are: Fc $\gamma$ R-mediated phagocytosis (CD45), TNF signaling-pathway (ICAM1, JUN), Toll-like receptor signaling-pathway (TLR1, JUN) and innate immune responses (ICAM1, TLR1, MBL2) (55). TLR1 encodes for a member of the Toll-like receptor family, and plays a fundamental role in pathogen recognition and activation of innate immunity $(30,56)$. TLR 1 was identified as a critical innate receptor for protective intestinal Th17 immunity (57) but, to our knowledge, has not been previously associated with increased susceptibility to infections, or hypogammaglobulinemia.

Two potentially damaging variants were identified in ICAM1, which encodes a cell surface glycoprotein involved in cell-cell adhesion, expressed on endothelial cells and cells of the immune system, and has a prominent role in several types of immune responses $(51,52)$. Variants in ICAM1 have been associated with inflammatory bowel disease (58). The p.G241R variant, which the twins inherited from their father, has been associated with adult onset celiac disease in a French cohort (59).

Flow-cytometry is crucial to the functional validation of genetic variants, allowing adequate interpretation of NGS data and stratification of patients $(25,26,60)$. Notably, we documented a synchronous progressive B-cell depletion throughout follow-up. Taking advantage of the EuroFlow strategy for highly-sensitive Ig-subclass analysis of blood B cells and plasma cells, six subgroups of patients were recently identified in CVID, with different IgG-switching patterns and clinical profiles, even in patients with $<1 \%$ B cells (7). The immunological phenotype of both twins at 50, was compatible with the CVID-6 subgroup, the most severe, defined by markedly decreased $\mathrm{CD}_{2} 7^{+}$unswitched and switched-memory B cells, with very low $\mathrm{CD}_{27}{ }^{-} \mathrm{IgG3}^{+}$memory B cells. CVID-6 patients also show significantly reduced pre-germinal B cells, reflecting defective B-cell production in the bone marrow $(61,62)$. These recently developed standardized flow-cytometry assays to analyse memory B-cell immunoglobulin isotypes and IgH-subclasses will be very important in longitudinal studies to investigate the progression of B-cell defects, that has been hypothesized, but not yet supported by solid immunological data $(7,8)$.

The remarkable similarity between the immune profiles of the MZ twins, at age 50, even though they have lived in different households since they were 25 , with distinct jobs and nuclear families, is even more striking in light of studies that have emphasized the dominant contribution of non-heritable influences to the shape and function of the immune system $(1,2)$. Although they live in the same geographical region, the impact of co-habitation has been considered very relevant in the shaping of the immune system, as illustrated by the immunological data from non-related housemates $(63,64)$. This debate on relative contributions of "nature" vs. "nurture" was addressed in a study that included 105 pairs of healthy MZ twins, which shows that variation in immune cell frequencies and serum proteins between twins increases with age, likely due in large part to exposure to pathogens, namely CMV (2). Notably, there has been no evidence of CMV infection in the MZ twins, both with negative PCR for $\mathrm{CMV}$ in blood on different occasions, and no evidence of CMV infection in gut biopsies.

Epigenetic modifications necessarily contribute to the discordance in clinical and immunological phenotype between MZ twins (1, 3). In line with this, a pair of MZ twins discordant for CVID was previously reported (3), with a significant increase in DNA methylation of B cells in the affected sister $(3,65)$. Consistent with this finding, a recent study showed that impaired demethylation in B-cell key genes is associated with the reduction of memory B cells in CVID patients (66). In our context, it will be interesting to explore the epigenetic landscape of the MZ concordant twins in order to confirm its contribution to the disease and add a new layer of insight to our clinical, immunological, and genomic data.

\section{CONCLUDING REMARKS}

The clinical, immunologic and genetic profile of a pair of monozygotic twins concordant for CVID provides further support to the hypothesis that a combination of allelic variants can additively predispose to non-familial CVID. Moreover, these data suggest that genetic variants may impose a significant constraint on the impact of the environment, as attested by the remarkably similar immunological phenotype observed in both twins, despite prolonged exposure to different living conditions. The integration of NGS data with clinical and immunological phenotypes at the single-cell level, as provided by multi-dimensional flow-cytometry, is crucial to further expose the complex genetic landscape underlying the vast majority of patients with CVID, and patients with other immunodeficiencies.

\section{DATA AVAILABILITY STATEMENT}

All datasets generated for this study are included in the manuscript/supplementary files. 


\section{ETHICS STATEMENT}

The studies involving human participants were reviewed and approved by Ethical boards of the Faculty of Medicine of University of Lisbon and Centro Hospitalar Universitário Lisboa Norte. The patients/participants provided their written informed consent to participate in this study. Written informed consent was obtained from the individuals for the publication of any potentially identifiable images or data included in this article.

\section{AUTHOR CONTRIBUTIONS}

SLS, MF, ABS, RV, and AES designed the study. SLS, MF, SPS, and RV collected the clinical data. MF, RB, AS-C, EB, and MP-A performed the immunological studies. MF, MP, PR, AR, MG-C, and LH analyzed WES data and investigated the selected variants.

\section{REFERENCES}

1. Brodin P, Davis MM. Human immune system variation. Nat Rev Immunol. (2017) 17:21-9. doi: 10.1038/nri.2016.125

2. Brodin P, Jojic V, Gao T, Bhattacharya S, Angel CJ, Furman D, et al. Variation in the human immune system is largely driven by non-heritable influences. Cell. (2015) 160:37-47. doi: 10.1016/j.cell.2014.12.020

3. Rodríguez-Cortez VC, Del Pino-Molina L, Rodríguez-Ubreva J, Ciudad L, Gómez-Cabrero D, Company C, et al. Monozygotic twins discordant for common variable immunodeficiency reveal impaired DNA demethylation during naive-to-memory B-cell transition. Nat Commun. (2015) 6:7335. doi: $10.1038 /$ ncomms 8335

4. Ameratunga R, Brewerton M, Slade C, Jordan A, Gillis D, Steele R, et al. Comparison of diagnostic criteria for common variable immunodeficiency disorder. Front Immunol. (2014) 5:415. doi: 10.3389/fimmu.2014.00415

5. Bonilla FA, Barlan I, Chapel H, Costa-Carvalho BT, Cunningham-Rundles C, de la Morena MT, et al. International Consensus Document (ICON): common variable immunodeficiency disorders. J Allergy Clin Immunol Pract. (2016) 4:38-59. doi: 10.1016/j.jaip.2015.07.025

6. Jolles $\mathrm{S}$. The variable in common variable immunodeficiency: a disease of complex phenotypes. J Allergy Clin Immunol Pract. (2013) 1:545-56; quiz 557. doi: 10.1016/j.jaip.2013.09.015

7. Blanco E, Pérez-Andrés M, Arriba-Méndez S, Serrano C, Criado I, Del PinoMolina L, et al. Defects in memory B-cell and plasma cell subsets expressing different immunoglobulin-subclasses in CVID and Ig-subclass deficiencies. $J$ Allergy Clin Immunol. (2019) 144:809-24. doi: 10.1016/j.jaci.2019.02.017

8. Blanco E, Pérez-Andrés M, Arriba-Méndez S, Contreras-Sanfeliciano T, Criado I, Pelak O, et al. Age-associated distribution of normal B-cell and plasma cell subsets in peripheral blood. J Allergy Clin Immunol. (2018) 141:2208-19.e16. doi: 10.1016/j.jaci.2018.02.017

9. Abolhassani H, Aghamohammadi A, Fang M, Rezaei N, Jiang C, Liu X, et al. Clinical implications of systematic phenotyping and exome sequencing in patients with primary antibody deficiency. Genet Med. (2019) 21:243-51. doi: 10.1038/s41436-018-0012-x

10. von Spee-Mayer C, Koemm V, Wehr C, Goldacker S, Kindle G, Bulashevska A, et al. Evaluating laboratory criteria for combined immunodeficiency in adult patients diagnosed with common variable immunodeficiency. Clin Immunol. (2019) 203:59-62. doi: 10.1016/j.clim.2019. 04.001

11. Kamin RM, Fudenberg HH, Douglas SD.Kamin RM, Fudenberg HH, Douglas SD. A genetic defect in "acquired" agammaglobulinemia. Proc Natl Acad Sci USA. (1968) 60:881-5. doi: 10.1073/pnas.60.3.881

12. Wu L, Schaid DJ, Sicotte H, Wieben ED, Li H, Petersen GM. Caseonly exome sequencing and complex disease susceptibility gene discovery: study design considerations. J Med Genet. (2015) 52:10-6. doi: 10.1136/jmedgenet-2014-102697
SLS, MF, ABS, AR, MG-C, LH, and AES discussed the results. SLS and AES supervised the study. SLS wrote the paper.

\section{FUNDING}

This work received funding from PAC - PRECISE - LISBOA01-0145-FEDER-016394, co-funded by FEDER through POR Lisboa 2020 - Programa Operacional Regional de Lisboa PORTUGAL 2020 and Fundação para a Ciência e a Tecnologia; and UID/BIM/50005/2019, project funded by Fundação para a Ciência e a Tecnologia (FCT)/Ministério da Ciência, Tecnologia e Ensino Superior (MCTES) through Fundos do Orçamento de Estado. Work in MG-C lab is supported by UID/MULTI/04046/2019 Research Unit grant from FCT, Portugal (to BioISI) and FCT research grant PTDC/BIA-CEL/29257/2017.
13. Orange JS, Glessner JT, Resnick E, Sullivan KE, Lucas M, Ferry B, et al. Genome-wide association identifies diverse causes of common variable immunodeficiency. J Allergy Clin Immunol. (2011) 127:1360-7.e6. doi: 10.1016/j.jaci.2011.02.039

14. Maffucci P, Filion CA, Boisson B, Itan Y, Shang L, Casanova $\mathrm{JL}$, et al. Genetic diagnosis using whole exome sequencing in common variable immunodeficiency. Front Immunol. (2016) 7:220. doi: $10.3389 /$ fimmu. 2016.00220

15. de Valles-Ibáñez G, Esteve-Solé A, Piquer M, González-Navarro EA, Hernandez-Rodriguez J, Laayouni $\mathrm{H}$, et al. Evaluating the genetics of common variable immunodeficiency: monogenetic model and beyond. Front Immunol. (2018) 9:636. doi: 10.3389/fimmu.2018.00636

16. van Schouwenburg PA, Davenport EE, Kienzler AK, Marwah I, Wright $B$, Lucas $M$, et al. Application of whole genome and RNA sequencing to investigate the genomic landscape of common variable immunodeficiency disorders. Clin Immunol. (2015) 160:301-14. doi: 10.1016/j.clim.2015.05.020

17. Yazdani R, Abolhassani H, Kiaee F, Habibi S, Azizi G, Tavakol M, et al. Comparison of common monogenic defects in a large predominantly antibody deficiency cohort. J Allergy Clin Immunol Pract. (2019) 7:864-78.e9. doi: 10.1016/j.jaip.2018.09.004

18. Kojima D, Wang X, Muramatsu H, Okuno Y, Nishio N, Hama A, et al. Application of extensively targeted next-generation sequencing for the diagnosis of primary immunodeficiencies. J Allergy Clin Immunol. (2016) 138:303-5.e3. doi: 10.1016/j.jaci.2016.01.012

19. Stray-Pedersen A, Sorte HS, Samarakoon P, Gambin T, Chinn IK, Coban Akdemir ZH, et al. Primary immunodeficiency diseases: genomic approaches delineate heterogeneous Mendelian disorders. J Allergy Clin Immunol. (2017) 139:232-45. doi: 10.1016/j.jaci.2016.05.042

20. Kienzler AK, Hargreaves CE, Patel SY. The role of genomics in common variable immunodeficiency disorders. Clin Exp Immunol. (2017) 188:326-32. doi: $10.1111 /$ cei.12947

21. Lvovs D, Favorova OO, Favorov AV. A polygenic approach to the study of polygenic diseases. Acta Nat. (2012) 4:59-71. doi: 10.32607/20758251-2012-4-3-59-71

22. van de Ven AA, Compeer EB, van Montfrans JM, Boes M. B-cell defects in common variable immunodeficiency: BCR signaling, protein clustering and hardwired gene mutations. Crit Rev Immunol. (2011) 31:85-98. doi: 10.1615/CritRevImmunol.v31.i2.10

23. Jørgensen SF, Fevang B, Aukrust P. Autoimmunity and inflammation in CVID: a possible crosstalk between immune activation, gut microbiota, and epigenetic modifications. J Clin Immunol. (2019) 39:30-6. doi: 10.1007/s10875-018-0574-Z

24. Berbers RM, Nierkens S, van Laar JM, Bogaert D, Leavis HL. Microbial dysbiosis in common variable immune deficiencies: evidence, causes, and consequences. Trends Immunol. (2017) 38:206-16. doi: 10.1016/j.it.2016.11.008 
25. Wehr C, Kivioja T, Schmitt C, Ferry B, Witte T, Eren E, et al. The EUROclass trial: defining subgroups in common variable immunodeficiency. Blood. (2008) 111:77-85. doi: 10.1182/blood-2007-06-091744

26. van der Burg M, Kalina T, Perez-Andres M, Vlkova M, Lopez-Granados E, Blanco E, et al. The EuroFlow PID orientation tube for flow cytometric diagnostic screening of primary immunodeficiencies of the lymphoid system. Front Immunol. (2019) 10:246. doi: 10.3389/fimmu.2019.00246

27. van der Velden VH, Flores-Montero J, Perez-Andres M, Martin-Ayuso M, Crespo O, Blanco E, et al. Optimization and testing of dried antibody tube: the EuroFlow LST and PIDOT tubes as examples. J Immunol Methods. (2017) 2017:e11. doi: 10.1016/j.jim.2017.03.011

28. Sunyaev S, Ramensky V, Koch I, Lathe W, Kondrashov AS, Bork P. Prediction of deleterious human alleles. Hum Mol Genet. (2001) 10:591-7. doi: $10.1093 / \mathrm{hmg} / 10.6 .591$

29. Kumar P, Henikoff S, Ng PC. Predicting the effects of coding non-synonymous variants on protein function using the SIFT algorithm. Nat Protoc. (2009) 4:1073-81. doi: 10.1038/nprot.2009.86

30. Lancioni CL, Li Q, Thomas JJ, Ding X, Thiel B, Drage MG, et al. Mycobacterium tuberculosis lipoproteins directly regulate human memory $\mathrm{CD}^{+}{ }^{+} \mathrm{T}$ cell activation via Toll-like receptors 1 and 2. Infect Immun. (2011) 79:663-73. doi: 10.1128/IAI.00806-10

31. Do HT, Baars W, Borns K, Windhagen A, Schwinzer R. The 77C-> G mutation in the human CD45 (PTPRC) gene leads to increased intensity of TCR signaling in $\mathrm{T}$ cell lines from healthy individuals and patients with multiple sclerosis. J Immunol. (2006) 176:931-8. doi: 10.4049/jimmunol.176.2.931

32. Picard C, Bobby Gaspar H, Al-Herz W, Bousfiha A, Casanova JL, Chatila $\mathrm{T}$, et al. International union of immunological societies: 2017 primary immunodeficiency diseases committee report on inborn errors of immunity. $J$ Clin Immunol. (2018) 38:96-128. doi: 10.1007/s10875-017-0464-9

33. Vorechovsky I, Kralovicova J, Tchilian E, Masterman T, Zhang Z, Ferry B, et al. Does 77C-> G in PTPRC modify autoimmune disorders linked to the major histocompatibility locus? Nat Genet. (2001) 29:22-3. doi: 10.1038/ng723

34. Tchilian EZ, Gil J, Navarro ML, Fernandez-Cruz E, Chapel H, Misbah S, et al. Unusual case presentations associated with the CD45 C77G polymorphism. Clin Exp Immunol. (2006) 146:448-54. doi: 10.1111/j.1365-2249.2006.03230.x

35. Conley ME, Dobbs AK, Farmer DM, Kilic S, Paris K, Grigoriadou S, et al. Primary B cell immunodeficiencies: comparisons and contrasts. Annu Rev Immunol. (2009) 27:199-227. doi: 10.1146/annurev.immunol.021908.132649

36. Barbosa RR, Silva SP, Silva SL, Melo AC, Pedro E, Barbosa MP, et al. Primary B-cell deficiencies reveal a link between human IL-17-producing CD4 T-cell homeostasis and B-cell differentiation. PLoS ONE. (2011) 6:e22848. doi: 10.1371/journal.pone.0022848

37. Flores-Montero J, Sanoja-Flores L, Paiva B, Puig N, García-Sánchez O, Böttcher S, et al. Next Generation Flow for highly sensitive and standardized detection of minimal residual disease in multiple myeloma. Leukemia. (2017) 31:2094-103. doi: 10.1038/leu.2017.29

38. Kalina T, Flores-Montero J, van der Velden VH, Martin-Ayuso M, Böttcher S, Ritgen M, et al. EuroFlow standardization of flow cytometer instrument settings and immunophenotyping protocols. Leukemia. (2012) 26:1986-2010. doi: 10.1038/leu.2012.122

39. Sousa AE, Chaves AF, Loureiro A, Victorino RM. Comparison of the frequency of interleukin (IL)-2-, interferon-gamma-, and IL-4-producing T cells in 2 diseases, human immunodeficiency virus types 1 and 2, with distinct clinical outcomes. J Infect Dis. (2001) 184:552-9. doi: 10.1086/322804

40. Abolhassani H, Wang N, Aghamohammadi A, Rezaei N, Lee YN, Frugoni F, et al. A hypomorphic recombination-activating gene 1 (RAG1) mutation resulting in a phenotype resembling common variable immunodeficiency. $J$ Allergy Clin Immunol. (2014) 134:1375-80. doi: 10.1016/j.jaci.2014.04.042

41. Romano R, Zaravinos A, Liadaki K, Caridha R, Lundin J, Carlsson $\mathrm{G}$, et al. NEIL1 is a candidate gene associated with common variable immunodeficiency in a patient with a chromosome $15 \mathrm{q} 24$ deletion. Clin Immunol. (2017) 176:71-6. doi: 10.1016/j.clim.2017.01.006

42. Fang M, Abolhassani H, Lim CK, Zhang J, Hammarström L. Next generation sequencing data analysis in primary immunodeficiency disorders-future directions. J Clin Immunol. (2016) 36 (Suppl. 1):68-75. doi: 10.1007/s10875-016-0260-y

43. Tchilian EZ, Beverley PC. Altered CD45 expression and disease. Trends Immunol. (2006) 27:146-53. doi: 10.1016/j.it.2006.01.001
44. Gil J, Ruiz-Tíscar JL, Rodríguez-Sainz C, Hernández A, Santamaría B, García-Sánchez F, et al. [Prevalence of C77G polymorphism in exon 4 of the CD45 gene in the Spanish population]. Med Clin. (2005) 125:10-1. doi: $10.1157 / 13076408$

45. Zikherman J, Weiss A. Alternative splicing of CD45: the tip of the iceberg. Immunity. (2008) 29:839-41. doi: 10.1016/j.immuni.2008.12.005

46. Wu Z, Yates AL, Hoyne GF, Goodnow CC. Consequences of increased CD45RA and RC isoforms for TCR signaling and peripheral T cell deficiency resulting from heterogeneous nuclear ribonucleoprotein L-like mutation. $J$ Immunol. (2010) 185:231-8. doi: 10.4049/jimmunol.0903625

47. Foletta VC, Segal DH, Cohen DR. Transcriptional regulation in the immune system: all roads lead to AP-1. J Leukoc Biol. (1998) 63:139-52. doi: 10.1002/jlb.63.2.139

48. Eisen DP, Minchinton RM. Impact of mannose-binding lectin on susceptibility to infectious diseases. Clin Infect Dis. (2003) 37:1496-505. doi: $10.1086 / 379324$

49. Sanui T, Inayoshi A, Noda M, Iwata E, Stein JV, Sasazuki T., et al.SDOCK2 regulates Rac activation and cytoskeletal reorganization through interaction with ELMO1. Blood. (2003) 102:2948-50. doi: 10.1182/blood-2003-01-0173

50. Nishihara $H$, Maeda $M$, Tsuda $M$, Makino $Y$, Sawa $H$, Nagashima $K$, et al. DOCK2 mediates $\mathrm{T}$ cell receptor-induced activation of Rac2 and IL-2 transcription. Biochem Biophys Res Commun. (2002) 296:716-20. doi: 10.1016/S0006-291X(02)00931-2

51. Verma NK, Kelleher D. Not just an adhesion molecule: LFA-1 contact tunes the T lymphocyte program. J Immunol. (2017) 199:1213-21. doi: 10.4049/jimmunol.1700495

52. Wingren AG, Parra E, Varga M, Kalland T, Sjogren HO, Hedlund G, et al. T cell activation pathways: B7, LFA-3, and ICAM-1 shape unique T cell profiles. Crit Rev Immunol. (2017) 37:463-81. doi: 10.1615/CritRevImmunol.v37.i2-6.130

53. Gil-Krzewska A, Wood SM, Murakami Y, Nguyen V, Chiang SCC, Cullinane AR, et al. Chediak-Higashi syndrome: lysosomal trafficking regulator domains regulate exocytosis of lytic granules but not cytokine secretion by natural killer cells. J Allergy Clin Immunol. (2016) 137:1165-77. doi: 10.1016/j.jaci.2015.08.039

54. Ban SA, Salzer E, Eibl MM, Linder A, Geier CB, Santos-Valente E, et al. Combined immunodeficiency evolving into predominant $\mathrm{CD} 4^{+}$ lymphopenia caused by somatic chimerism in JAK3. J Clin Immunol. (2014) 34:941-53. doi: 10.1007/s10875-014-0088-2

55. Kanehisa M, Furumichi M, Tanabe M, Sato Y, Morishima K. KEGG: new perspectives on genomes, pathways, diseases and drugs. Nucleic Acids Res. (2017) 45:D353-61. doi: 10.1093/nar/gkw1092

56. Whitmore LC, Hook JS, Philiph AR, Hilkin BM, Bing X, Ahn C, et al. A common genetic variant in TLR1 enhances human neutrophil priming and impacts length of intensive care stay in pediatric sepsis. J Immunol. (2016) 196:1376-86. doi: 10.4049/jimmunol.1500856

57. DePaolo RW, Kamdar K, Khakpour S, Sugiura Y, Wang W, Jabri B. A specific role for TLR1 in protective $\mathrm{T}(\mathrm{H}) 17$ immunity during mucosal infection. J Exp Med. (2012) 209:1437-44. doi: 10.1084/jem.20112339

58. Braun C, Zahn R, Martin K, Albert E, Folwaczny C. Polymorphisms of the ICAM-1 gene are associated with inflammatory bowel disease, regardless of the p-ANCA status. Clin Immunol. (2001) 101:357-60. doi: 10.1006/clim.2001.5118

59. Abel M, Cellier C, Kumar N, Cerf-Bensussan N, Schmitz J, Caillat-Zucman $\mathrm{S}$. Adulthood-onset celiac disease is associated with intercellular adhesion molecule-1 (ICAM-1) gene polymorphism. Hum Immunol. (2006) 67:612-7. doi: 10.1016/j.humimm.2006.04.011

60. Warnatz K, Denz A, Dräger R, Braun M, Groth C, Wolff-Vorbeck G, et al. Severe deficiency of switched memory B cells $\left(\mathrm{CD} 27^{+} \operatorname{IgM}^{-} \operatorname{IgD}^{-}\right)$ in subgroups of patients with common variable immunodeficiency: a new approach to classify a heterogeneous disease. Blood. (2002) 99:1544-51. doi: 10.1182/blood.V99.5.1544

61. Driessen GJ, van Zelm MC, van Hagen PM, Hartwig NG, Trip M, Warris A, et al. B-cell replication history and somatic hypermutation status identify distinct pathophysiologic backgrounds in common variable immunodeficiency. Blood. (2011) 118:6814-23. doi: 10.1182/blood-2011-06-361881

62. Ochtrop ML, Goldacker S, May AM, Rizzi M, Draeger R, Hauschke $\mathrm{D}$, et al. $\mathrm{T}$ and $\mathrm{B}$ lymphocyte abnormalities in bone marrow biopsies 
of common variable immunodeficiency. Blood. (2011) 118:309-18. doi: 10.1182/blood-2010-11-321695

63. Carr EJ, Dooley J, Garcia-Perez JE, Lagou V, Lee JC, Wouters C, et al. The cellular composition of the human immune system is shaped by age and cohabitation. Nat Immunol. (2016) 17:461-8. doi: 10.1038/ni.3371

64. Liston A, Carr EJ, Linterman MA. Shaping variation in the human immune system. Trends Immunol. (2016) 37:637-46. doi: 10.1016/j.it.2016. 08.002

65. Li J, Wei Z, Li YR, Maggadottir SM, Chang X, Desai A, et al. Understanding the genetic and epigenetic basis of common variable immunodeficiency disorder through omics approaches. Biochim Biophys

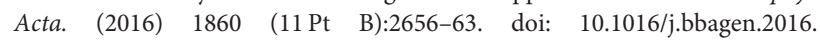
06.014

66. Del Pino-Molina L, Rodríguez-Ubreva J, Torres Canizales J, Coronel-Díaz M, Kulis M, Martín-Subero JI, et al. Impaired CpG demethylation in common variable immunodeficiency associates with B cell phenotype and proliferation rate. Front Immunol. (2019) 10:878. doi: 10.3389/fimmu.2019.00878

Conflict of Interest: The authors declare that the research was conducted in the absence of any commercial or financial relationships that could be construed as a potential conflict of interest.

Copyright (C) 2019 Silva, Fonseca, Pereira, Silva, Barbosa, Serra-Caetano, Blanco, Rosmaninho, Pérez-Andrés, Sousa, Raposo, Gama-Carvalho, Victorino, Hammarstrom and Sousa. This is an open-access article distributed under the terms of the Creative Commons Attribution License (CC BY). The use, distribution or reproduction in other forums is permitted, provided the original author(s) and the copyright owner(s) are credited and that the original publication in this journal is cited, in accordance with accepted academic practice. No use, distribution or reproduction is permitted which does not comply with these terms. 